\title{
Nitrosation of Thiols and Thioethers \\ in the Gas Phase: A Combined Theoretical and Experimental Study
}

\author{
Pascal Gerbaux, ${ }^{*}$ Pascale Wantier, and Robert Flammang \\ Organic Chemistry Laboratory, University of Mons-Hainaut, Mons, Belgium
}

\begin{abstract}
Recent studies have demonstrated the biological importance of the interaction of nitric oxide with proteins such as cytochrome-c or hemoglobin. In particular, the possibility that the nitrosonium cation, $\mathrm{NO}^{+}$, could reversibly bind to sulfide atom type was proposed. At $\mathrm{pH}$ values of biological relevance, nitrosation was proposed to occur through the action of $\mathrm{NO}^{+}$ carriers such as nitrosothiols or nitrosamines. In this context, the gas phase chemistry of protonated nitrosothiols is studied in the present work by a combination of mass spectrometry and computational methods. (J Am Soc Mass Spectrom 2004, 15, 344-355) () 2004 American Society for Mass Spectrometry
\end{abstract}

$\mathrm{T}$ The emergence of $\mathrm{NO}$ as a cell signaling agent is one of the most important and exciting developments in human physiology during the last decade. It was first recognized that endogenous vasodilators such as acetylcholine do not act directly on vascular smooth muscle but instead on endothelial cells, causing them to release a labile factor that diffuses into the overlying smooth muscle. The search for the identity of this endothelial-derived relaxing factor (EDRF) intensified during the 1980s. It was already known that a number of compounds that can release NO, and even NO itself, will activate the key enzyme involved in smooth muscle relaxation and it was proposed that EDRF might be NO or a related species [1]. These days it is well known that nitric oxide is involved in a range of such processes including, not only vasodilation, but also platelet aggregation, macrophage activity, messenger action in the central nervous system, etc. [2]. The multiplicity of biological functions so far attributed to NO has led to suggestions that some effects might be mediated by other related species instead, since it is difficult to imagine how one so simple molecule could fulfil them all [3]. Among the investigated NO-derived species, i.e., peroxynitrite, nitroxide ion, nitrosonium cation [1-3], S-nitrosothiols are suspected to be a carrier of $\mathrm{NO}^{+}$at physiological $\mathrm{pH}$ [4]. Indeed, the interaction of NO with biological thiol compounds such as glutathione and cysteine residues of proteins is of great interest, particularly because reversible nitrosothiolation of specific cysteine residues on proteins may serve

Published online January 15, 2004

Address reprint requests to Dr. P. Gerbaux, Organic Chemistry Laboratory, University of Mons-Hainaut, 19 Avenue Maistriau, B-7000 Mons, Belgium. E-mail: pascal.gerbaux@umh.ac.be

*Also a research associate of the Fonds National pour la Recherche Scientifique, Brussels, Belgium. as a way of regulating protein function. In this context, it was recently proposed that the oxygen transport properties of hemoglobin are so controlled [5]. Nitric oxide $\left(\mathrm{NO}^{\bullet}\right)$ itself is relatively unreactive toward thiols, but it can be oxidized in vivo to the nitrosonium ion (or a nitrosonium ion carrier) which can react with thiols to form nitrosothiols [6].

Recently, it was proposed and demonstrated by means of quantum chemistry that $\mathrm{NO}^{+}$cation can also interact with other biological molecules bearing sulfur, specifically thioethers [2]. This theoretical work led to the conclusion that the nitrosonium cation is able to attack the thioether moiety with the initial formation of $S$-nitroso sulfonium [2].

In the present work, we endeavor to experimentally and theoretically investigate the gas phase nitrosation of some simple thiols and thioethers in order to shed some light on the intrinsic and relative stabilities of the obtained nitrosated species and in order to get some pieces of information related to their potent intervention in biological processes.

\section{Experimental and Theoretical Procedures}

\section{Methods}

The mass spectrometric experiments were performed on a large scale tandem mass spectrometer (Micromass AutoSpec 6F, Manchester, UK) having a $\mathrm{C}_{1} \mathrm{E}_{1} \mathrm{~B}_{1} \mathrm{c}_{2} \mathrm{E}_{2} \mathrm{C}_{3} \mathrm{C}_{4} \mathrm{E}_{3} \mathrm{~B}_{2} \mathrm{c}_{5} \mathrm{E}_{4}$ geometry, where $\mathrm{E}$ stands for electric sector, $\mathrm{B}$ for magnetic sector, and $\mathrm{C}$ for the collision cells [7]. Typical conditions were $8 \mathrm{kV}$ accelerating voltage, $1 \mathrm{~mA}$ emission current (in the chemical ionization mode), $200 \mu \mathrm{A}$ (in the electron ionization mode), and $70 \mathrm{eV}$ ionizing electron kinetic energy. The solid samples were introduced with a direct insertion 
probe, whereas the liquid samples were injected into the ion source via a heated septum inlet $\left(180^{\circ} \mathrm{C}\right)$. This instrument has been modified with an rf-only quadrupole collision cell between $\mathrm{E}_{2}$ and $\mathrm{E}_{3}$ as reported elsewhere [8]. This modification allows the study of associative ion-molecule reactions of decelerated ions having about $5 \mathrm{eV}$ kinetic energy. Briefly, the experiments using the quadrupole consist of the selection of a beam of fast moving ions $(8000 \mathrm{eV})$ with the three first sectors and the deceleration of these ions to approximately $5 \mathrm{eV}$ before entering the quadrupole in order to maximize the yields of the associative ion-molecule reactions between the ions and the neutral reagent (pressure estimated to be ca. $10^{-3}$ torr). After reacceleration to $8000 \mathrm{eV}$, all the ions generated in the quadrupole cell are separated and mass-measured by scanning the field of the second magnet. The high-energy CA spectra of mass-selected ion-molecule reaction ionic products can be recorded by a linked scanning of the fields of the last three sectors (collision in $\mathrm{c}_{4}$ ) or by scanning the field of the last electric sector after massselection by the second magnet and collision in the fifth $\left(c_{5}\right)$ collision cell.

All the compounds considered in this work were commercially available and were used without any further purification.

\section{Calculations}

Standard ab initio and density functional theory calculations were performed using the GaussianW 98 suite of programs [9]. Geometries were first optimized by density functional theory using Becke's hybrid functional (B3LYP) and the 6-31 + G(d,p) basis set. Harmonic vibrational frequencies were computed on each optimized structure at its corresponding level of theory. This enables us to access the nature of the stationary points, to verify that they correspond to true minima on the potential surface and also to estimate the zero-point vibrational energy (ZPE) corrections. To compute accurate relative energies, we have employed the higherlevel theoretical G2 method and in particular the G2(MP2) modified version. This computational method is amply recognized as being able to reproduce or predict unknown thermochemical data of compounds containing first- and second-row atoms with a target accuracy of about $8 \mathrm{~kJ} \mathrm{~mol}^{-1}$ [10].

\section{Results and Discussion}

Nitrosonium complexes of organic compounds have been the subject of an impressive number of papers reporting experimental gas and condensed phases as well as theoretical studies [11]. As far as the nitrogen-, oxygen- and sulfur-containing compounds are concerned, namely $\left[\mathrm{R}_{1} \mathrm{XR}_{2}+\mathrm{NO}^{+}\right.$where $\mathrm{X}=\mathrm{NH}, \mathrm{O}$ or $\mathrm{S}$ and $\mathrm{R}_{1}, \mathrm{R}_{2}=\mathrm{H}$ and/or $\mathrm{CH}_{3}$, a rapid survey of the literature, see Table 1, reveals dramatic discrepancies in the reported $\mathrm{NO}^{+}$affinities (NOA) for the neutral substrate, NOA being defined as the binding energy of the $\mathrm{NO}^{+}$cation on a neutral molecule. Because of such a wide range of reported values and because it was recently shown that the theoretical study of nitrosonium complexes is dramatically basis set dependent [12], we first decided to perform high accuracy calculations using G2(MP2) theory that is well-known to give reliable thermochemical data. We then considered the interaction between the nitrosonium cation and six different compounds, namely ammonia, water, hydrogen sulfide, methylamine, methanol, and methanethiol. The optimized structures are shown in Figure 1 and the main geometrical parameters are summarized in Table 2.

\section{$1^{\circ}$ Systematic G2(MP2) Theoretical Study}

\section{Nitrosonium Complexes of Ammonia and Methylamine}

The cationic complex between ammonia and $\mathrm{NO}^{+}$, namely $N$-protonated nitrosamide, has already been theoretically studied and experimentally observed by reacting ammonia and $\mathrm{NO}^{+}$in a chemical ionization source [24]. It was demonstrated that the $N$-protonated species, $\mathrm{NH}_{3}^{+}-\mathrm{NO}$, is the most stable isomer $[13,18,19$, 22] and that the eclipsed conformer 1a , see Figure 1, is a true minimum while the staggered cation represents a rotational transition state [18]. In the present study, all this information is obviously confirmed, but in addition, we obtained very accurate thermochemical data, such as $\mathrm{NOA}\left(\mathrm{NH}_{3}\right)=125.7 \mathrm{~kJ} \mathrm{~mol}^{-1}, \mathrm{PA}\left(\mathrm{NH}_{3}\right)=847.2$ $\mathrm{kJ} \mathrm{mol}{ }^{-1}, \mathrm{PA}\left(\mathrm{NH}_{2} \mathrm{NO}\right)=795.1 \mathrm{~kJ} \mathrm{~mol}^{-1}$, IE $\left(\mathrm{NH}_{3}\right)=$ $10.2 \mathrm{eV}$, and IE $\left(\mathrm{NO}^{\circ}\right)=9.25 \mathrm{eV}$. These intrinsic properties are compared with the known data in Table 3 and since all the PA and IE values are in really good agreement with the reference data, we can be quite confident in our NOA (ammonia) calculated value of $125.7 \mathrm{~kJ} \mathrm{~mol}^{-1}$.

The substitution of an hydrogen atom by a methyl group, yielding methylamine, was then considered. The starting point of the G2(MP2) calculation was the geometry optimized by Nguyen and Hegarty, Structure $\mathbf{1 b}$ in Figure 1, and identified as the most stable conformer [22]. Following the G2(MP2) calculation, the NOA was shown to undergo an increase upon methylation of about $53 \mathrm{~kJ} \mathrm{~mol}^{-1}$ [NOA (methylamine) $=178.8$ $\mathrm{kJ} \mathrm{mol}^{-1}$ ], see Tables 1 and 3 . The most stable conformer corresponds to the Structure $\mathbf{1 b}$, shown in Figure 1, and presents an "endo" geometry with the oxygen atom of the $\mathrm{NO}$ group pointing in the direction of a hydrogen of the methyl moiety. Nevertheless, the bond length O9-H3 amounting to about $2.3 \AA$ is too long to be considered as a true hydrogen bonding.

\section{Nitrosonium Complexes of Water and Methanol}

Protonated nitrous acid was also extensively studied because of the multiple roles that this species is sup- 
Table 1. Survey of the $\mathrm{NO}^{+}$affinities NOA $\left(\mathrm{kJ} \mathrm{mol}^{-1}\right)$ reported in the literature

\begin{tabular}{|c|c|c|c|c|c|c|c|}
\hline & $\mathrm{NH}_{3}$ & $\mathrm{OH}_{2}$ & $\mathrm{SH}_{2}$ & $\mathrm{CH}_{3} \mathrm{NH}_{2}$ & $\mathrm{CH}_{3} \mathrm{OH}$ & $\mathrm{CH}_{3} \mathrm{SH}$ & $\mathrm{CH}_{3} \mathrm{SCH}_{3}$ \\
\hline Ref. 1 & 151.9 & - & - & - & - & - & - \\
\hline Ref. 2 & - & 77.4 & - & - & 105.8 & - & - \\
\hline Ref. 3 & & 77.4 & & & & & \\
\hline Ref. 4 & & & & & 151.4 & & \\
\hline Ref. 5 & 138.9 & 77.4 & 84.1 & 155.6 & 97.5 & 109.2 & \\
\hline Ref. 6 & 130.1 & & & & & & \\
\hline Ref. 7 & 128.4 & & & & & & \\
\hline Ref. 8 & 122.0 & 78 & 77 & & & & \\
\hline Ref. 9 & 110.1 & 88.2 & 50.2 & 127.5 & 96.6 & 84.7 & \\
\hline Ref. 10 & & 81.6 & & & & & \\
\hline Ref. 11 & & & & & & & 143.0 \\
\hline Ref. 12 & & & & & & & 184.1 \\
\hline Ref. 13 & 136.8 & & 140.1 & & & & \\
\hline Ref. 14 & & 76 & & & & & \\
\hline Ref. 15 & 129.7 & & & & & & \\
\hline Ref. 16 & & 77.4 & & & & & \\
\hline Ref. 17 & 125.7 & 77.9 & 80.6 & 178.8 & 102.1 & 132.2 & - \\
\hline
\end{tabular}

Ref. 1 Theoretical study-MP2/6-31G(d,p) [13]

Ref. 2 Theoretical study-G2 procedure [14]

Ref. 3 Experimental study-high pressure ionization source study [15].

Ref. 4 Experimental study-ICR study [16].

Ref. 5 Experimental study-ICR study \& kinetic method [17].

Ref. 6 Theoretical study-G2 procedure [18].

Ref. 7 Theoretical study-estimation based on PA [18].

Ref. 8 Theoretical study-CCSD(T)/6-311++G(3df,2p) [19].

Ref. 9 Theoretical study-HF/6-31+G(d) [20].

Ref. 10 Theoretical study-G1 procedure [21].

Ref. 11 Theoretical study-HF/3-21G* + ZPE [2].

Ref. 12 Theoretical study-CBS-4 procedure [2].

Ref. 13 Theoretical study-MP4SDQ/6-31++G** +ZPE [22]

Ref. 14 Theoretical study-HF/6-31G** [23].

Ref. 15 Theoretical study-MNDO calculations [24].

Ref. 16 Theoretical study-MNDO calculations [12]

Ref. 17 Present work - G2(MP2) energies.

posed to play both in the condensed phase and the atmospheric chemistries, see Table 1 . Gaseous $\mathrm{H}_{2} \mathrm{O}^{+} \mathrm{NO}$ cations have been obtained by chemical ionization and various reactions have been successfully employed for their preparation, e.g., the addition of nitrosonium cation on neutral water, or the ethene loss from ethyl nitrite upon highly exothermic protonation by $\mathrm{H}_{3}^{+}$and $\mathrm{CH}_{5}^{+}$[21]. It was also demonstrated that the ion-dipole adduct is by far the most stable protomer and that the non planar Structure 2a, see Figure 1, represents the most stable conformer [12]. At the G2(MP2) level of theory, we therefore recalculated the NOA (water) and obtained a value of $77.9 \mathrm{~kJ} \mathrm{~mol}^{-1}$ that is in very good agreement with the previously reported values, see Table 1.

Protonated methyl nitrite, $\mathbf{2} \mathbf{b}$, was also studied by Aschi and Grandinetti and their theoretical investigation revealed that the $O$-protonated species, namely the ion-dipole adduct between methanol and $\mathrm{NO}^{+}$, again represents by far the most stable protomer [14]. At the G2 level of theory [14], the dissociation enthalpy into $\mathrm{MeOH}$ and $\mathrm{NO}^{+}$was computed at $105.8 \mathrm{~kJ} \mathrm{~mol}^{-1}$, see Table 1. Starting from the reported geometry, we obtained at the G2(MP2) level of theory a quite similar value of $102.1 \mathrm{~kJ} \mathrm{~mol}^{-1}$. Again, in the water/methanol system, the NOA value is shown to be increased upon methylation. As for the methylamine case, the "endo" geometry $\mathbf{2} \mathbf{b}$ seems, at least at the level of theory used here, to represent the more stable conformer.

\section{Nitrosonium Complexes of Hydrogen Sulfide and Methanethiol}

Investigations of the interaction of the $\mathrm{NO}^{+}$cation with $\mathrm{O}$ - and $\mathrm{S}$-bases using perturbation theory demonstrated that the nitrosonium cation acts as a soft acid [27]. According to the Pearson concept [28], the complexes of $\mathrm{NO}^{+}$cation with $S$-bases should be more stable than those with $O$-bases. This was experimentally demonstrated since the condensed phase reaction of thioanisole with $\mathrm{NOAlCl}_{4}$ afforded an $n$-complex, whereas the reaction with anisole gave rise to a $\pi$-complex [29]. The preferential binding of $\mathrm{NO}^{+}$cation at the sulfur atom rather than at the oxygen atom in the thioanisole/ anisole sytem was attributed to the lower electronegativity of the $S$ atom and a greater $p, \pi$-conjugation of the aromatic fragment with the $\mathrm{MeO}$ group compared with that of the MeS group [29]. For the sake of information, let us just mention that the $\pi$-complexes of aromatic compounds with $\mathrm{NO}^{+}$have also been extensively studied, especially in the context of charge transfer complexes [30].

The nitroso sulfonium cation, $\mathrm{H}_{2} \mathrm{~S}^{+}-\mathrm{NO}$ (3a), was 


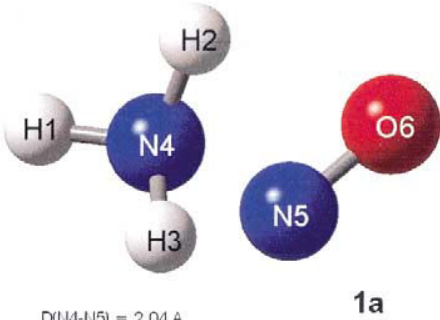

$D(14-1 N 5)=2.04 \mathrm{~A}$
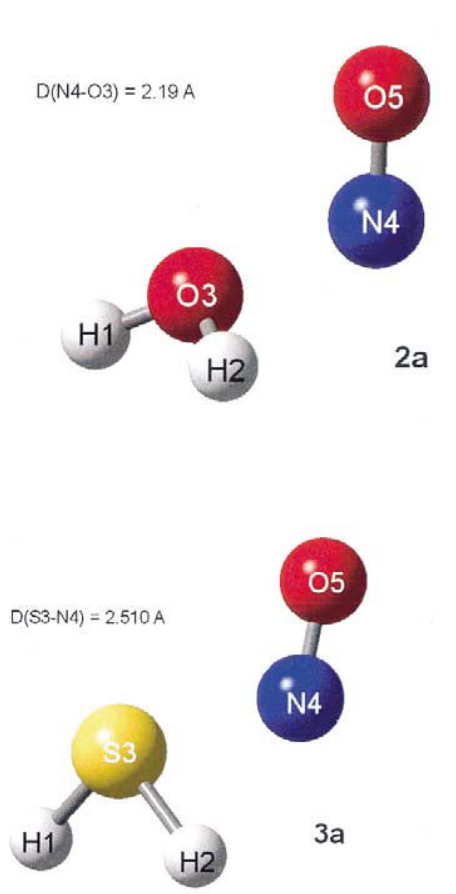

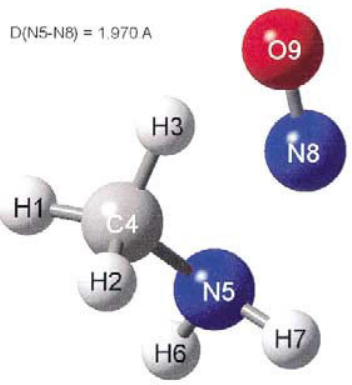

1b

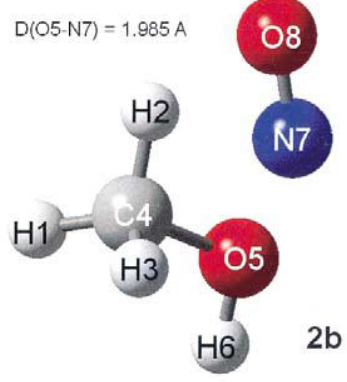

08

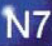

$D(S 5-N 7)=2.387 A$

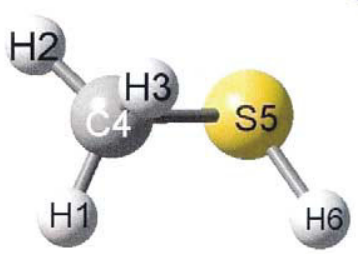

$3 b$

Figure 1. Optimized geometries of the nitrosonium complexes of water, methanol, ammonia, methylamine, hydrogen sulfide and methanethiol (G2(MP2) calculations-MP2/6-31G(d) level of theory).

prepared in the gas phase by reacting neutral nitric oxide with $\mathrm{CH}_{2} \mathrm{CH}_{2} \mathrm{SH}_{2}^{+}$, the distonic isomer of ionized ethanethiol [19]. Those cations were characterized by collisional activation and neutralization-reionization studies. Ab initio calculations, see Table 1, confirmed that, while $\mathrm{H}_{2} \mathrm{~S}^{+}-\mathrm{NO}$ (3a) is stable with respect to fragmentation, it can be best regarded as a strong molecular complex between $\mathrm{NO}^{+}$and $\mathrm{H}_{2} \mathrm{~S}$ rather than an onium cation. This cation exhibits a non-symmetrical structure which is slightly distorted from the syn form having an $\mathrm{C}_{\mathrm{s}}$-symmetry. The latter is characterized as a transition structure for rotation of both $\mathrm{NO}$ and $\mathrm{H}_{2} \mathrm{~S}$ groups around the single $\mathrm{S}-\mathrm{N}$ bond [19]. This optimized structure was used in the present work as the starting point for our G2(MP2) calculations and, at this level of theory, we obtained a NOA value of $80.6 \mathrm{~kJ} \mathrm{~mol}^{-1}$ that is in quite a good agreement with the value of $77 \mathrm{~kJ}$ $\mathrm{mol}^{-1}$ reported by Nguyen et al. [19]. It is important to emphasize that, at the G2(MP2) level of theory, the
$\operatorname{NOA}\left(\mathrm{H}_{2} \mathrm{O}\right)$ is calculated to be lower than the $\operatorname{NOA}\left(\mathrm{H}_{2} \mathrm{~S}\right)$. This ordering is in keeping with the experimental study of Cacace et al. [17], but at variance with the theoretical values obtained by Torday et al. [20], and to a less extent, by Nguyen et al. [19], see Table 1.

Much less is reported on the nitrosonium complex of methanethiol 3b. A theoretical study at the HF/6$31 G(d)$ level of theory was recently realized [20] and a NOA value of $84.7 \mathrm{~kJ} \mathrm{~mol}^{-1}$ was computed. This figure can be compared with the more accurate calculated value of $132.2 \mathrm{~kJ} \mathrm{~mol}^{-1}$ obtained in the present G2(MP2) study. The most important geometrical information is that, at variance with the structures of the nitrosonium cation complexes of methylamine and methanol, it was not possible in the case of the methanethiol molecule to detect the endo conformer as a local minimun and each attempt to locate such a structure always converged toward the exo species, see Figure 1 and Table 2. 
Table 2. G2(MP2) optimized parameters of nitrosonium complexes of selected $\mathrm{N}_{-}, \mathrm{O}-$, and $\mathrm{S}$-bases

\begin{tabular}{|c|c|c|c|c|}
\hline Species & & $\begin{array}{l}\text { Bond length } \\
(\AA)\end{array}$ & Bond angle $\left({ }^{\circ}\right)$ & Dihedral angle $\left(^{\circ}\right)$ \\
\hline$\left[\mathrm{NH}_{3}, \mathrm{NO}\right]^{+}$ & $1 \mathrm{a}$ & $\begin{array}{l}\mathrm{H} 1-\mathrm{N} 4: 1.024 \\
\mathrm{H} 2-\mathrm{N} 4: 1.024 \\
\mathrm{H} 3-\mathrm{N} 4: 1.024 \\
\mathrm{~N} 4-\mathrm{N} 5: 2.040 \\
\mathrm{~N} 5-06: 1.120\end{array}$ & $\begin{array}{l}\mathrm{H} 1 \mathrm{~N} 4 \mathrm{H} 2: 109.7 \\
\mathrm{H} 1 \mathrm{~N} 4 \mathrm{~N} 5: 106.9 \\
\text { N4N5O6:112.3 }\end{array}$ & $\begin{array}{l}\text { H1N4N5O6:121.6 } \\
\text { H2N4N5O:6.0 }\end{array}$ \\
\hline$\left[\mathrm{H}_{2} \mathrm{O}, \mathrm{NO}\right]^{+}$ & $2 a$ & $\begin{array}{l}\mathrm{H} 1-\mathrm{O} 3: 0977 \\
\mathrm{H} 2-\mathrm{O}: 0.977 \\
\mathrm{O} 3-\mathrm{N} 4: 2.190 \\
\mathrm{~N} 4-\mathrm{O} 5: 1100\end{array}$ & $\begin{array}{l}\mathrm{H} 1 \mathrm{O} 3 \mathrm{H} 2: 104.8 \\
\mathrm{H} 1 \mathrm{O} 3 \mathrm{~N} 4: 119.4 \\
\text { O3N405:100.2 }\end{array}$ & H1O3N4O5:114.5 \\
\hline$\left[\mathrm{H}_{2} \mathrm{~S}, \mathrm{NO}\right]^{+}$ & $3 a$ & $\begin{array}{l}\text { H1-S3:1345 } \\
\text { H2-S3:1.345 } \\
\text { S3-N4:2.510 } \\
\text { N4-O5:1.120 }\end{array}$ & $\begin{array}{l}\text { H1S3H2:94.5 } \\
\text { H1S3N4:94.9 } \\
\text { S3N4O5:112.3 }\end{array}$ & H153N4O5:132.8 \\
\hline$\left[\mathrm{CH}_{3} \mathrm{NH}_{2}, \mathrm{NO}\right]^{+}$ & $1 b$ & $\begin{array}{l}\mathrm{H} 1-\mathrm{C} 4: 1089 \\
\mathrm{H} 2-\mathrm{C} 4: 1.089 \\
\mathrm{H} 3-\mathrm{C} 4: 1.089 \\
\mathrm{C} 4-\mathrm{N} 5: 1.460 \\
\mathrm{~N} 5-\mathrm{H} 6: 1.020 \\
\mathrm{~N} 5-\mathrm{H} 7: 1.020 \\
\mathrm{~N} 5-\mathrm{N} 8: 1.970 \\
\mathrm{~N} 8-09: 1.140\end{array}$ & $\begin{array}{l}\mathrm{H} 1 \mathrm{C} 4 \mathrm{H} 2: 110.1 \\
\mathrm{H} 1 \mathrm{C} 4 \mathrm{~N} 5: 109.6 \\
\mathrm{C} 4 \mathrm{~N} 5 \mathrm{H} 6: 115.6 \\
\mathrm{~N} 5 \mathrm{~N} 809: 108.8\end{array}$ & $\begin{array}{l}\text { H1C4N5H6:-29.6 } \\
\text { C4N5N8O9:10.8 }\end{array}$ \\
\hline$\left[\mathrm{CH}_{3} \mathrm{OH}, \mathrm{NO}\right]^{+}$ & $2 b$ & $\begin{array}{l}\mathrm{H} 1-\mathrm{C} 4: 1.090 \\
\mathrm{H} 2-\mathrm{C} 4: 1.090 \\
\mathrm{H} 3-\mathrm{C} 4: 1.090 \\
\mathrm{C} 4-\mathrm{O} 5: 1.450 \\
\text { O5-H6:0.980 } \\
\text { O5-N7:1.980 } \\
\text { N7-O8:1.120 }\end{array}$ & $\begin{array}{l}\mathrm{H} 1 \mathrm{C} 4 \mathrm{H} 2: 110.9 \\
\mathrm{H} 1 \mathrm{C} 4 \mathrm{O} 5: 111.3 \\
\mathrm{C} 4 \mathrm{OH} 6: 111.1 \\
\text { C4O5N7:116.8 } \\
\text { O5N7O8:108.2 }\end{array}$ & $\begin{array}{l}\mathrm{H} 1 \mathrm{C} 4 \mathrm{O} 5 \mathrm{H} 6:-47.1 \\
\mathrm{C} 405 \mathrm{~N} 708: 31.9\end{array}$ \\
\hline$\left[\mathrm{CH}_{3} \mathrm{SH}, \mathrm{NO}\right]^{+}$ & $3 b$ & $\begin{array}{l}\mathrm{H} 1-\mathrm{C} 4: 1.080 \\
\mathrm{H} 2-\mathrm{C} 4: 1.080 \\
\mathrm{H} 3-\mathrm{C} 4: 1.080 \\
\mathrm{C} 4-\mathrm{S} 5: 1.810 \\
\text { S5-H6:1.340 } \\
\text { S5-N7:2.380 } \\
\text { N7-O8:1.130 }\end{array}$ & $\begin{array}{l}\mathrm{H} 1 \mathrm{C} 4 \mathrm{H} 2: 110.1 \\
\mathrm{H} 1 \mathrm{C} 4 \mathrm{S5}: 109.3 \\
\mathrm{C} 4 \mathrm{~S} 5 \mathrm{H} 6: 98.5 \\
\text { C4S5N7:90.0 } \\
\text { S5N708:117.1 }\end{array}$ & $\begin{array}{l}\text { H1C4S5H6:-53.5 } \\
\text { C4S5N708:-161.5 }\end{array}$ \\
\hline$\left[\mathrm{CH}_{3} \mathrm{SCH}_{3}, \mathrm{NO}\right]^{+}$ & 3c & $\begin{array}{l}\mathrm{H}-\mathrm{C} 1: 1.094 \\
\mathrm{C} 1-\mathrm{S} 3: 1.820\end{array}$ & $\begin{array}{l}\text { HC1S3:110.5 } \\
\text { C1S3C2:101.8 }\end{array}$ & $\begin{array}{l}\text { HC1S3C2:58.4 } \\
\text { C1S3N4O5:-129.0 }\end{array}$ \\
\hline B3LYP/6-31+G(d,p) & & $\begin{array}{l}\text { C2-S3:1.820 } \\
\text { S3-N4:2.280 } \\
\text { N4-O5:1.120 }\end{array}$ & $\begin{array}{l}\text { C1S3N4:93.0 } \\
\text { S3N4O5:116.0 } \\
\text { S5N708:117.1 }\end{array}$ & \\
\hline
\end{tabular}

\section{Summary}

At the G2(MP2) level of theory, the nitrosonium cation affinities of $\mathrm{H}_{3} \mathrm{~N}, \mathrm{H}_{2} \mathrm{O}, \mathrm{H}_{2} \mathrm{~S}, \mathrm{MeNH}_{2}, \mathrm{MeOH}$ and $\mathrm{MeSH}$ are calculated, respectively, as follow; see also Tables 1 and 3: 125.7, 77.9, 80.6, 178.8, 102.1, and $132.2 \mathrm{~kJ} \mathrm{~mol}^{-1}$. These values allow us to conclude that the NOA's increase when going from an $\mathrm{O}$-base to an $\mathrm{N}$-base via an $S$-base and also increase upon replacement of a hydrogen atom by a methyl group. Together with this increase of the NOA's, the methylation always shortens the $\mathrm{ON}-\mathrm{X}$ distance in the adduct ions (Figure 1 and Table 2).

To theoretically study the thioether derivatives, we decided to perform DFT calculations using the popular B3LYP model and the $6-31+\mathrm{G}(\mathrm{d}, \mathrm{p})$ basis set instead of the much more resource-consuming G2(MP2) method.

\section{$2^{\circ}$ DFT Calculations on the Thioether/ $\mathrm{NO}^{+}$Complexes}

First of all, for the sake of comparison and coherence, we decided to perform the B3LYP/6-31 + G(d,p) calculations on the methanethiol system already studied at the G2(MP2) level of theory, see Table 3. The data resulting from the DFT calculations are summarized in Table 4 and we immediately observed some dramatic discrepancies between both theoretical approaches. Indeed, the NOA data are calculated to be about $50 \mathrm{~kJ}$ $\mathrm{mol}^{-1}$ overestimated by the B3LYP calculations when compared with the G2(MP2) results, see Tables 3 and 4 . Using DFT calculations, we obtained the following values: $\operatorname{NOA}\left(\mathrm{NH}_{3}\right)=184.7 \mathrm{~kJ} \mathrm{~mol}^{-1} ; \mathrm{NOA}\left(\mathrm{CH}_{3} \mathrm{SH}\right)=$ $186.7 \mathrm{~kJ} \mathrm{~mol}^{-1}$, and $\mathrm{NOA}\left(\mathrm{CH}_{3} \mathrm{SCH}_{3}\right)=228.4 \mathrm{~kJ} \mathrm{~mol}^{-1}$. Even if these data significantly differ from the G2(MP2) 
Table 3. IE (eV), PA $\left(\mathrm{kJ} \mathrm{mol}^{-1}\right)$, and NOA $\left(\mathrm{kJ} \mathrm{mol}^{-1}\right)$ calculated in the present work at the G2(MP2) level of theory

\begin{tabular}{lccc}
\hline Neutral species & $\mathrm{IE}(\mathrm{eV})$ & $\mathrm{PA}\left(\mathrm{kJ} \mathrm{mol}^{-1}\right)$ & $\left.\mathrm{NOA}(\mathrm{kJ} \mathrm{mol})^{-1}\right)$ \\
\hline \hline $\mathrm{NO}$ & $9.25(9.25)^{\mathrm{a}}$ & - & - \\
$\mathrm{NH}_{3}$ & $10.2(10.16)$ & $847.2(853.6)$ & 125.7 \\
$\mathrm{OH}_{2}$ & $12.6(12.6)$ & $682.2(697)$ & 78.0 \\
$\mathrm{SH}_{2}$ & $10.4(10.45)$ & $704.8(712)$ & 80.6 \\
$\mathrm{CH}_{3} \mathrm{NH}_{2}$ & $9.11(8.97)$ & $895.1(896)$ & 178.76 \\
$\mathrm{CH}_{3} \mathrm{OH}$ & $10.98(10.85)$ & $748.7(761)$ & 102.1 \\
$\mathrm{CH}_{3} \mathrm{SH}$ & $9.44(9.44)$ & $773.3(784)$ & 132.2 \\
& & & - \\
$\mathrm{HONO}_{\mathrm{NH}} \mathrm{NO}$ & - & $782.7(785.3)^{\mathrm{b}}$ & - \\
$\mathrm{HSNO}$ & - & $795.1(800.4)^{\mathrm{c}}$ & - \\
$\mathrm{CH}_{3} \mathrm{ONO}$ & - & $795.1(760)^{\mathrm{d}}$ & - \\
$\mathrm{CH}_{2} \mathrm{NHNO}$ & - & $777.3(797)^{\mathrm{e}}$ & - \\
$\mathrm{CH}_{3} \mathrm{SNO}$ & - & $810.9(-)$ & \\
\hline
\end{tabular}

aThe reference values (between brackets) come from ref. [25], except noted.

${ }^{b}$ from ref. [15].

cfrom ref. [18].

${ }^{d}$ from ref. [19].

efrom ref. [26].

values, the NOA ordering observed at the G2(MP2) level of theory seems to be confirmed.

As far as the dimethyl sulfide compound is concerned (not obtained at the G2(MP2) level), the structure of the $\mathrm{NO}^{+}$complex is described in Figure 2. It is important to emphasize that the $[\mathrm{MeSMe}, \mathrm{NO}]^{+}$species possesses the highest calculated binding energy (228.4 $\mathrm{kJ} \mathrm{mol}^{-1}$ ) between the neutral substrate and the nitrosonium cation.

\section{$3^{\circ}$ Preparation and Characterization of $\mathrm{NO}^{+}$Complexes: Nitrosation of Thiols and Thioethers}

To the best of our knowledge, experimental direct observations of thiol and thioether nitrosonium complexes have scarcely been reported. Spanel and Smith have recently performed a SIFT study [Selected Ion Flow Tube studies] of the reactions of $\mathrm{NO}^{+}$with some organosulphur molecules [31]. This study revealed that
$\mathrm{NO}^{+}$reactions mainly proceed via charge transfer producing the thio compound molecular ions. Nevertheless, the reaction with ethanethiol was shown to be more complicated leading inter alia to the ion molecule adduct $\left[\mathrm{C}_{2} \mathrm{H}_{5} \mathrm{SH}, \mathrm{NO}\right]^{+}$. A recent work described the electrospray analysis of physiological and synthetic $S$-nitroso compounds including S-nitrosoglutathione and $S$-nitrosocysteine and the protonated species were detected in the ESI mass spectrum [32].

The electronic ionization of a mixture of nitric oxide and $\mathrm{R}_{1} \mathrm{SR}_{2}$ (methanethiol, ethanethiol, propanethiol, dimethylsulfide, and diethylsulfide) under chemical ionization conditions always leads to the addition of $\mathrm{NO}^{+}$to the thio substrate. Based on the G2(MP2) calculations presented here that, without doubt, the NOA is drastically increased when going from an $O$-substrate to an $S$-substrate, we can expect to perform the nitrosation of thiols and thioethers by interaction with a protonated alkyl nitrite, actually the nitrosonium complex of an alcohol [14-26] (vide infra). These reac-

Table 4. IE (eV), PA $\left(\mathrm{kJ} \mathrm{mol}^{-1}\right)$ and NOA $\left(\mathrm{kJ} \mathrm{mol}^{-1}\right)$ calculated in the present work at the B3LYP/6-31+G(d,p) level of theory

\begin{tabular}{lccc}
\hline Neutral species & $\mathrm{IE}(\mathrm{eV})$ & $\mathrm{PA}\left(\mathrm{kJ} \mathrm{mol}^{-1}\right)$ & $\left.\mathrm{NOA}(\mathrm{kJ} \mathrm{mol})^{-1}\right)$ \\
\hline \hline $\mathrm{NO}$ & $9.92(9.25)^{\mathrm{a}}$ & - & - \\
$\mathrm{NH}_{3}$ & $10.1(10.16)$ & $850.2(853.6)$ & 184.7 \\
$\mathrm{CH}_{3} \mathrm{SH}$ & $9.36(9.44)$ & $765.3(784)$ & 186.7 \\
$\mathrm{CH}_{3} \mathrm{SCH}$ & $8.59(8.69)$ & $818.5(830.9)$ & 228.4 \\
$\mathrm{CH}_{3} \mathrm{CH}_{2} \mathrm{CH}_{2} \mathrm{ONO}$ & - & 788.3 & - \\
$\mathrm{CH}_{3} \mathrm{CH}_{2} \mathrm{CH}_{2} \mathrm{OH}$ & - & $781.7(800.4)^{\mathrm{b}}$ & - \\
$\mathrm{NH}_{2} \mathrm{NO}$ & - & $(-)$ & - \\
$\mathrm{CH}_{3} \mathrm{SNO}$ & - & & - \\
\hline
\end{tabular}

aThe reference values (between brackets) come from ref. [25], except otherwise noted.

bFrom ref. [18]. 


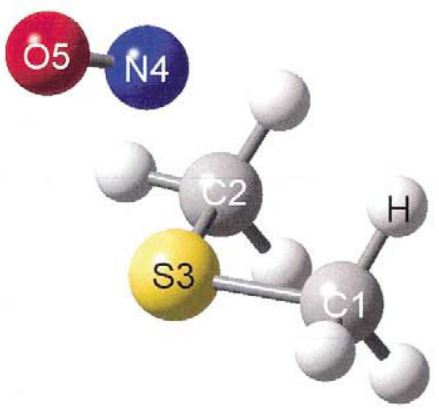

Figure 2. Optimized geometry of the nitrosonium complex of dimethyl sulfide (B3LYP/6-31 + G(d,p) level of theory).

tions were attained in the CI source by ionizing a mixture of propyl nitrite and $R_{1} S R_{2}$ and, whatever the nature of the starting thio compound was, the nitrosation process was observed to be really efficient, since the corresponding signals always represent at least $50 \%$ of the base peak.

We then decided to submit all the $\mathrm{NO}^{+}$complexes to collision in order to get information related to their structures. The recorded CA spectra are summarized in Table 5 and a characteristic example is shown in Figure $3 \mathrm{a}$ corresponding to the $\mathrm{CA}$ spectrum of the $\left[\mathrm{CH}_{3} \mathrm{SH}, \mathrm{NO}\right]^{+}$ions. As a general rule, protonated nitrosothiol, $\left[\mathrm{R}_{1} \mathrm{SH}, \mathrm{NO}\right]^{+}$cations, undergo upon collisional activation a cleavage into $\mathrm{R}_{1} \mathrm{SH}+\mathrm{NO}^{*}$ with the positive charge remaining either on the thiol compound or

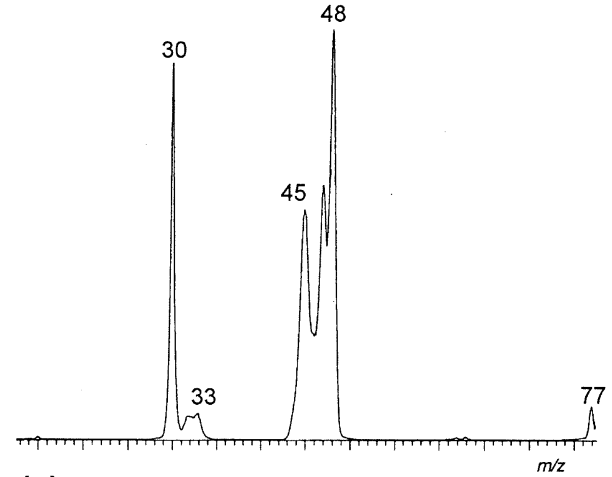

(a)

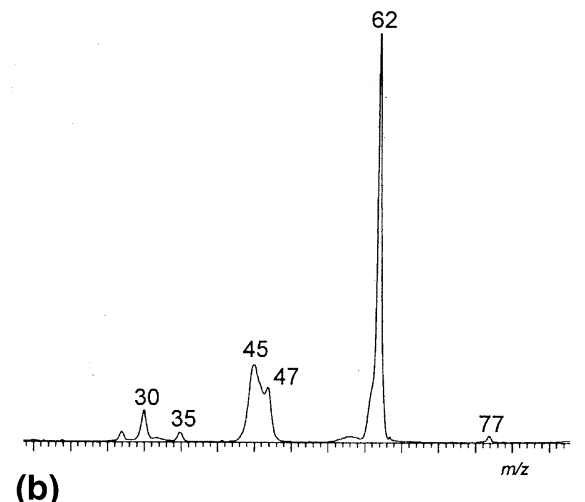

Figure 3. CID spectra (8000 eV kinetic energy, $\mathrm{N}_{2}$ collision gas) of (a) $\left[\mathrm{CH}_{3} \mathrm{SH}, \mathrm{NO}^{+}{ }^{(m / z ~ 78)}\right.$ and $(\mathbf{b})\left[\mathrm{CH}_{3} \mathrm{SCH}_{3}, \mathrm{NO}^{+}(\mathrm{m} / z\right.$ 92) complexes.

Table 5. CID Spectra (8 keV, $\mathrm{N}_{2}$ collision gas) of $\left[\mathrm{R}_{1} \mathrm{SR}_{2}, \mathrm{NO}\right]^{+}$complexes

\begin{tabular}{|c|c|c|}
\hline $\mathrm{R}_{1} \mathrm{SR}_{2}$ & Parent ions & Fragment ions $\left[I_{\text {rel }}(\%)\right]$ \\
\hline $\mathrm{CH}_{3} \mathrm{SH}$ & $m / z 78$ & $\begin{array}{l}m / z 77(8)-\text { loss of } \mathrm{H} \\
m / z 48(100)-\text { loss of } \mathrm{NO} \\
m / 247(62-\text { loss of } \mathrm{H}, \mathrm{N}, \mathrm{O} \\
m / 245(56)-\mathrm{CHS}^{+} \text {cations } \\
m / z 33(10)-\mathrm{HS}^{+} \text {cations } \\
m / 230(94)-\text { loss of } \mathrm{MeSH}\end{array}$ \\
\hline $\mathrm{CH}_{3} \mathrm{CH}_{2} \mathrm{SH}$ & $m / z 92$ & $\begin{array}{l}m / 262(100)-\text { loss of } \mathrm{NO}^{\bullet} \\
m / 261(72)-\text { loss of } \mathrm{H}, \mathrm{N}, \mathrm{O}-\text { metastable reaction } \\
\mathrm{m} / \mathrm{z} 45(18)-\mathrm{CHS}^{+} \text {cations } \\
\mathrm{m} / \mathrm{z} 35(10)-\mathrm{H}_{3} \mathrm{~S}^{+} \text {cations } \\
\mathrm{m} / \mathrm{z} 30(32)-\text { loss of } \mathrm{E}+\mathrm{SH}\end{array}$ \\
\hline $\mathrm{CH}_{3} \mathrm{CH}_{2} \mathrm{CH}_{2} \mathrm{SH}$ & $m / z 106$ & $\begin{array}{l}m / 276(100)-\text { loss of } \mathrm{NO}{ }^{\bullet} \\
m / z 75(30)-\text { loss of } \mathrm{H}, \mathrm{N}, \mathrm{O}-\text { metastable reaction } \\
m / 247(18)-\mathrm{CH}_{3} \mathrm{~S}^{+} \text {cations } \\
m / 245(10)-\mathrm{CHS}^{+} \text {cations } \\
m / 242(20) \\
m / 230(10)-\text { loss of PropylSH }\end{array}$ \\
\hline $\mathrm{CH}_{3} \mathrm{SCH}_{3}$ & $m / z 92$ & $\begin{array}{l}m / z 77(1)-\text { loss of } \mathrm{CH}_{3}{ }^{\circ} \\
m / z 62(100)-\text { loss of } \mathrm{NO}^{\bullet}-\text { metastable reactions } \\
m / z 47(15)-\mathrm{CH}_{3} \mathrm{~S}^{+} \text {cations } \\
m / z 45(20)-\mathrm{CHS}^{+} \text {cations } \\
m / z 35(4)-\mathrm{H}_{3} \mathrm{~S}^{+} \text {cations } \\
m / z 30(8)-\text { loss of MeSMe }\end{array}$ \\
\hline $\mathrm{CH}_{3} \mathrm{CH}_{2} \mathrm{SCH}_{2} \mathrm{CH}_{3}$ & $\mathrm{~m} / \mathrm{z} 120$ & 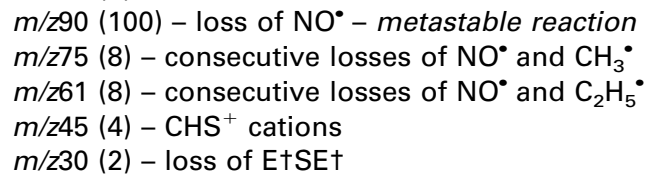 \\
\hline
\end{tabular}




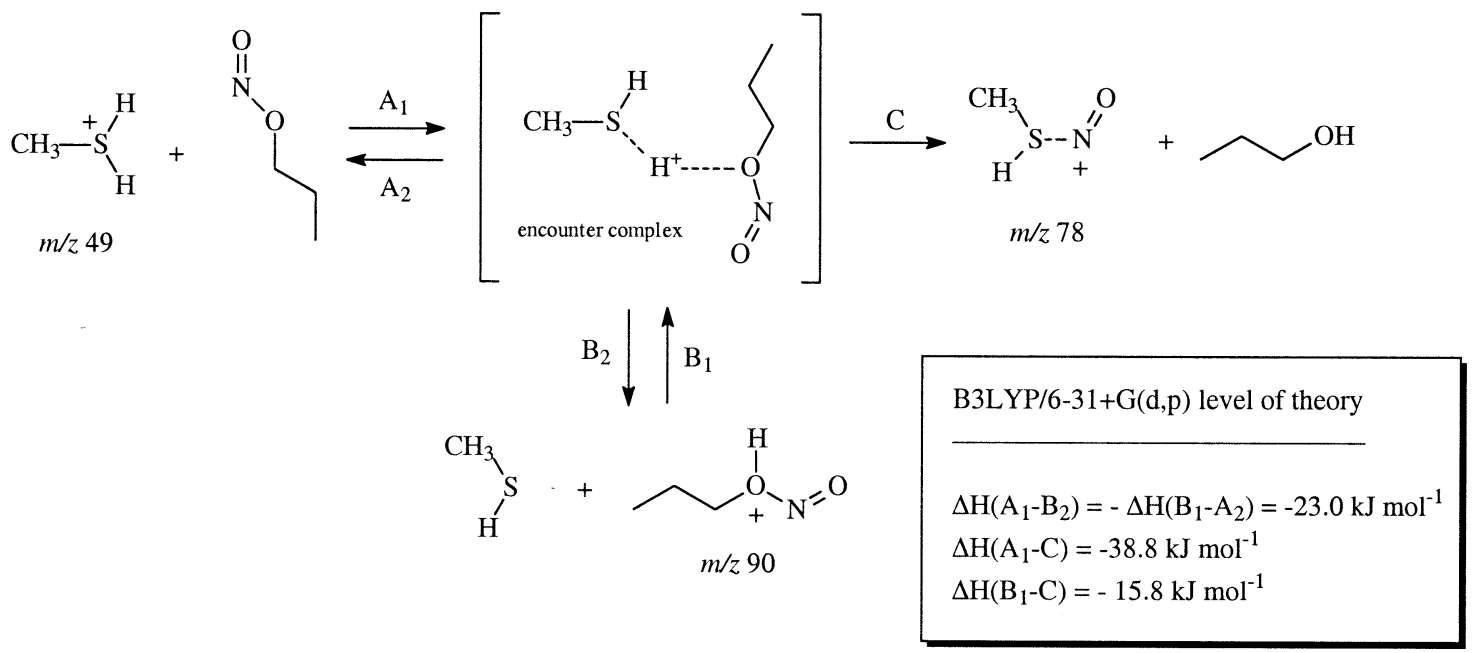

Scheme 1

on the nitric oxide molecule since the IE of the thiol molecules are quite similar to the IE of nitric oxide, $\mathrm{IE}(\mathrm{NO})=9.25 \mathrm{eV}, \mathrm{IE}(\mathrm{MeSH})=9.44 \mathrm{eV}, \mathrm{IE}(\mathrm{EtSH})=9.28$ $\mathrm{eV}$ and IE(PropylSH) $=9.19 \mathrm{eV}$ [25]. Consecutive decompositions of the $\mathrm{R}_{1} \mathrm{SH}$ molecular ions are responsible for the remaining signals observed in the CA spectra. As far as the metastable decomposition is concerned, the complexes incorporating the ethanethiol or the propanethiol molecule expel a molecule of nitrosyl hydride $(\mathrm{H}-\mathrm{N}=\mathrm{O})$.

The main collision-induced fragmentation of the thioether nitrosonium complexes also leads to the formation of ionized thioether and neutral nitric oxide or to the formation of ionized nitric oxide plus neutral thioether, see a typical example in Figure 3b. Again, even if the ionization energies of dimethyl and diethyl sulfides (8.69 and $8.43 \mathrm{eV}$, respectively [25]), are lower than the IE of nitric oxide, it is possible to observe in the CA spectra a weak but significant signal corresponding to ionized nitric oxide; see Table 5 . Even if the loss of nitric oxide is by far the most favorable process upon collisional activation, this fragmentation also possesses an unimolecular component since it is observed also in the absence of the collision gas. Again, consecutive decompositions of thioether molecular ions, produced in the CA cell by NO loss, are responsible for the remaining signals appearing in the CA spectra, see Table 5.

\section{$4^{\circ}$ Nitrosonium Cation Transfer in the Thiol (Thioether)/Alkyl Nitrite System}

We have described here above that the chemical ionization of a mixture of an alkyl nitrite and a thio compound inter alia leads to the production of the nitrosonium cation complex of the thio species. Because the ionic and neutral populations are incredibly complex in the CI source, it is impossible at this point of the work to identify the reacting species in the observed reaction. In order to overcome this problem, we decided to selectively probe the potential reactions described in Scheme 1 owing to the use of the quadrupole cell. Moreover, we calculated at the B3LYP/6-31 + G(d,p) level of theory the heats of these reactions in order to provide some quantitative support to our experimental observations.

The interaction between protonated methanethiol $(m / z 49)$ and propyl nitrite, Reaction $A_{1}$ in Scheme $\mathbf{1}$, is presented in Figure $4 \mathrm{a}$ and leads to several different ionic products: protonated propyl nitrite $(\mathrm{m} / \mathrm{z} 90$ - via Reaction $\mathrm{B}_{2}$ ) and methanethiol nitrosonium complex $(\mathrm{m} / \mathrm{z} 78$ - via Reaction $\mathrm{C})$. The proton affinity of methanethiol amounts to $765.3 \mathrm{~kJ} \mathrm{~mol}^{-1}$ (DFT calculations, see Table 4). On the other hand, to the best of our knowledge, the PA of propyl nitrite is hitherto unknown. Actually, protonation of propyl nitrite could in principle occur at three different centers on the $\mathrm{O}-\mathrm{N}=\mathrm{O}$ group. However, recent works on alkyl nitrite protonation reveal that the protonation process always leads to the $[\mathrm{AlkylOH}-\mathrm{NO}]^{+}$cations that is by far the most stable species. For instance in the methyl nitrite case, the energy difference between the $[\mathrm{MeOH}-\mathrm{NO}]^{+}$and the $[\mathrm{MeO}-$ $\mathrm{NOH}]^{+}$species is computed as large as $120 \mathrm{~kJ} \mathrm{~mol}^{-1}$ [14]. Therefore, we decided to calculate the PA of propyl nitrite at the propyl-O-N=O oxygen atom. At the B3LYP/6-31 + G(d,p) level of theory, we obtained a value of $788.3 \mathrm{~kJ} \mathrm{~mol}^{-1}$, see Table 4 . The proton transfer reaction between protonated methanethiol and propyl nitrite is then calculated to be exothermic by about 23.0 $\mathrm{kJ} \mathrm{mol}^{-1}$, and consequently the observation of protonated propyl nitrite is of course rationalized. Both signals detected at $m / z 88$ and 59, see Figure 4a, could correspond to fragment ions of protonated propyl nitrite (losses of $\mathrm{H}_{2}$ and $\mathrm{HNO}$, respectively). At the B3LYP/ 6-31 $+\mathrm{G}(\mathrm{d}, \mathrm{p})$ level of theory, as presented in Scheme 1, the $\mathrm{NO}^{+}$cation transfer process (Reaction A1-C) is calculated to be exothermic by $38.8 \mathrm{~kJ} \mathrm{~mol}^{-1}$. This finding is of course totally in keeping with the observation of the corresponding ionic products, since exo- 


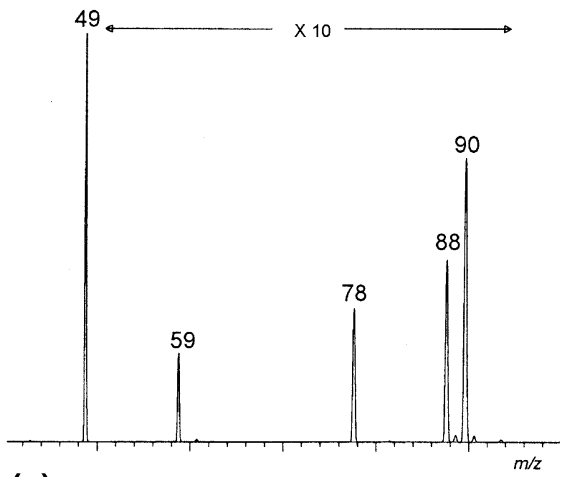

(a)

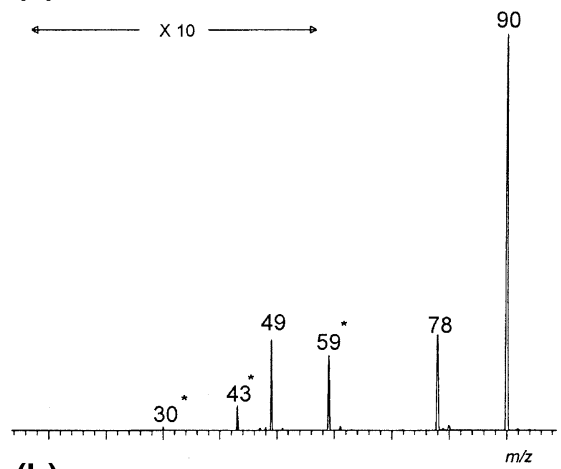

(b)

Figure 4. Ion-molecule reactions between (a) mass-selected protonated methanethiol $(\mathrm{m} / \mathrm{z} 49)$ and neutral propyl nitrite and (b) mass-selected protonated propyl nitrite $(\mathrm{m} / \mathrm{z} 90)$ and methanethiol in the quadrupole cell. The signals marked by an asterisk correspond to the metastable decomposition product of the massselected ions.

thermic reactions are always favored in the gas phase. Actually, a state-of-the-art analysis of ion-molecule reactions requires the consideration of entropic and kinetic (transition barriers) effects together with the energetic data. Nevertheless, it was generally admitted that the endothermic-exothermic criterion is often decisive when a qualitative analysis of a gas phase process is considered.
On the other hand, the interaction between protonated propyl nitrite and methanethiol in the quadrupole cell gives rise with a very high yield and via Reactions $\mathrm{B}_{1}-\mathrm{C}$, see Scheme 1 , to the transfer of $\mathrm{NO}^{+}$to the neutral reagent $(\mathrm{m} / \mathrm{z} 78$ in Figure $4 \mathrm{~b})$. The observation of this process is in close agreement with the theoretical approach that reveals an exothermicity of $15.8 \mathrm{~kJ} \mathrm{~mol}^{-1}$ for the $\mathrm{NO}^{+}$transfer from protonated propylnitrite to methanethiol; see Scheme 1. The proton transfer to methanethiol is also observed even if endothermic (by $23.0 \mathrm{~kJ} \mathrm{~mol}^{-1}$ ) but the occurrence of endothermic processes in our experimental setting is not unexpected since no thermalization step precedes the ion-molecule reaction processes and therefore hot ions can not be expelled from the ion beam. Nevertheless, the yield of this reaction is quite limited and the produced cations appear at $m / z 49$ (via Reaction $\mathrm{B}_{1}-\mathrm{A}_{2}$ ).

The same experiences were realized with dimethyl sulfide. First, the interaction between protonated dimethyl sulfide and neutral propyl nitrite is allowed in the quadrupole cell - see Scheme 2 (Reaction $\mathrm{A}_{1}$ ) and Figure $5 \mathrm{a}$. The main observed process leads to the $\left[\mathrm{MeSMe}, \mathrm{NO}^{+}\right.$] complex detected at $m / z$ 92. This is in close agreement with our quantum calculations (DFT) that reveal that the $\mathrm{A}_{1}-\mathrm{C}$ sequence of reactions is $27.3 \mathrm{~kJ}$ $\mathrm{mol}^{-1}$ exothermic whereas the proton transfer process is an endothermic process $\left(30.2 \mathrm{~kJ} \mathrm{~mol}^{-1}\right.$, see Scheme 2$)$. Nevertheless, protonated propyl nitrite $(\mathrm{m} / \mathrm{z} 90)$ is also produced but in a very small extent; see Figure 5a.

The $\left[\mathrm{MeSMe}, \mathrm{NO}^{+}\right]$complex is also readily generated when reacting protonated propyl nitrite $(\mathrm{m} / \mathrm{z} 90)$ with neutral dimethyl sulfide (Reaction $\mathrm{B}_{1}-\mathrm{C}$ in Scheme 2). This process is accordingly calculated to be exothermic by $57.5 \mathrm{~kJ} \mathrm{~mol}^{-1}$. Competitively, the ionic product of the sequence of Reactions $B_{1}-A_{2}$, also an exothermic process, is detected and the corresponding signal is observed at $\mathrm{m} / \mathrm{z} 63$ (protonated dimethyl sulfide). $M / z 62$ ions observed in Figure 5b (ionized methyl sulfide) are likely to arise from the partial decomposition of $\mathrm{m} / \mathrm{z} 92$ ions generated in the associative process, decomposi-

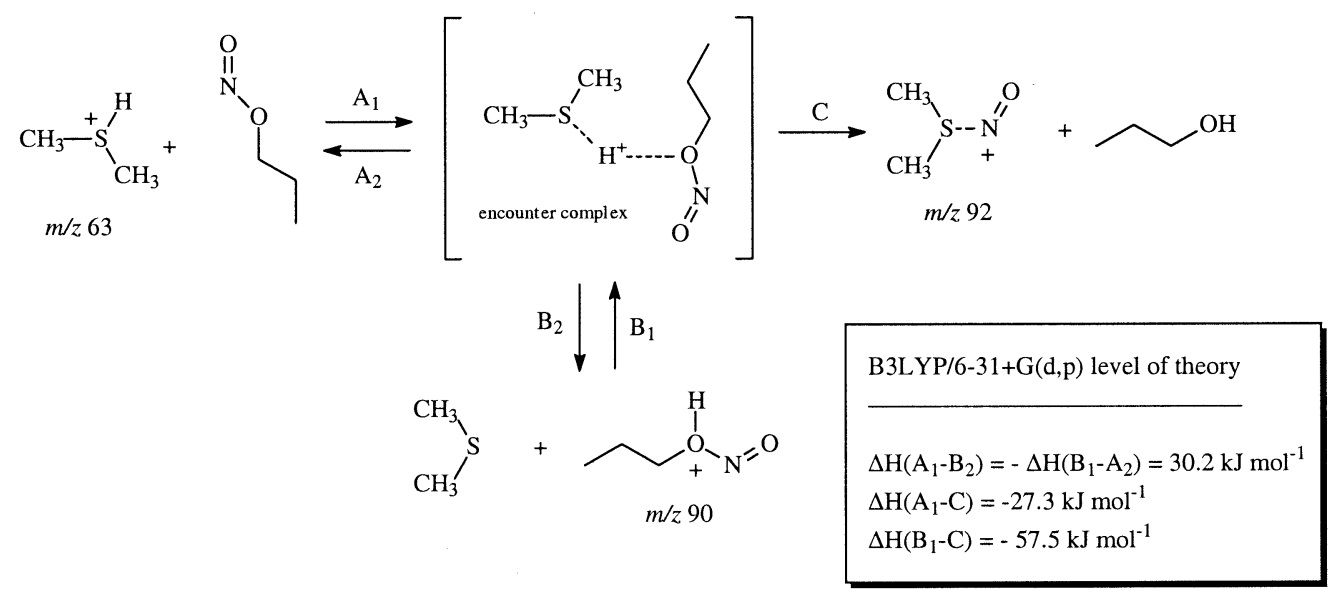

Scheme 2 


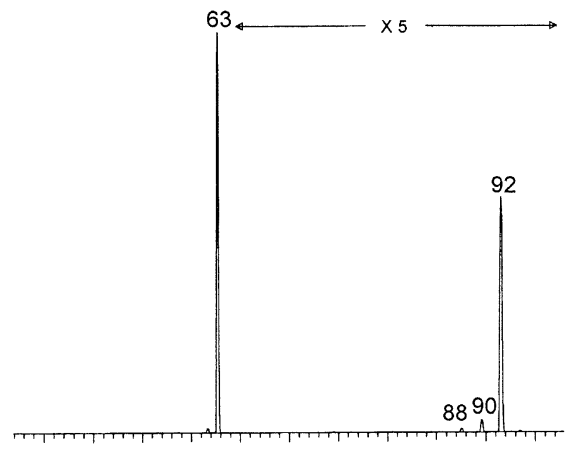

(a)

$\mathrm{m} / \mathrm{z}$

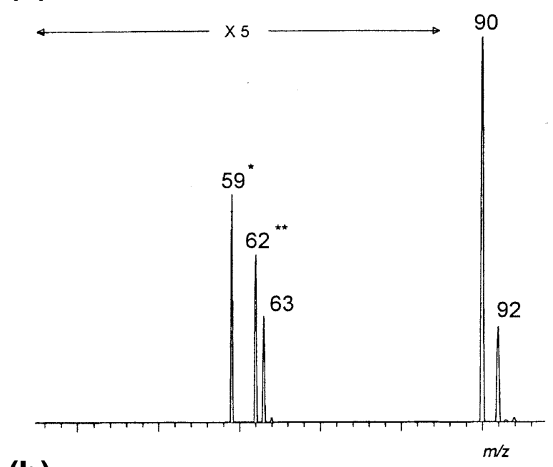

(b)

Figure 5. Ion-molecule reactions between (a) mass-selected protonated dimethyl sulfide $(\mathrm{m} / \mathrm{z} 63)$ and neutral propyl nitrite and (b) mass-selected protonated propyl nitrite $(\mathrm{m} / \mathrm{z} 90)$ and dimethyl sulfide in the quadrupole cell. The signals marked by an asterisk correspond to the metastable decomposition product of the massselected ions; (see text).

tion probably induces by the high exothermicity of the reaction.

These experimental data allow us to conclude that (1) a proton is required in the nitrosation of thiol by alkyl nitrite, (2) that in the gas phase this proton could be initially borne either by the thiol compound or the nitrite, and (3) since proton transfer type reactions are observed, that a protonated dimer can be proposed as the intermediate species.

\section{$5^{\circ}$ Ion-Molecule Reactions of Thiols and Thioethers $\mathrm{NO}^{+}$Complexes}

In order to qualitatively probe the validity of our G2(MP2) and B3LYP studies, we decided to allow the thiols and thioethers $\mathrm{NO}^{+}$complexes to react with

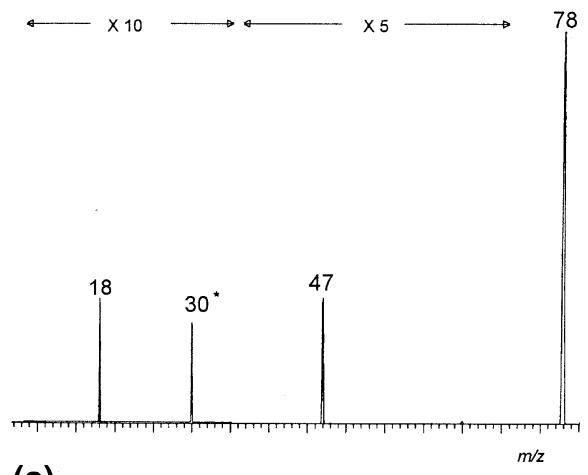

(a)

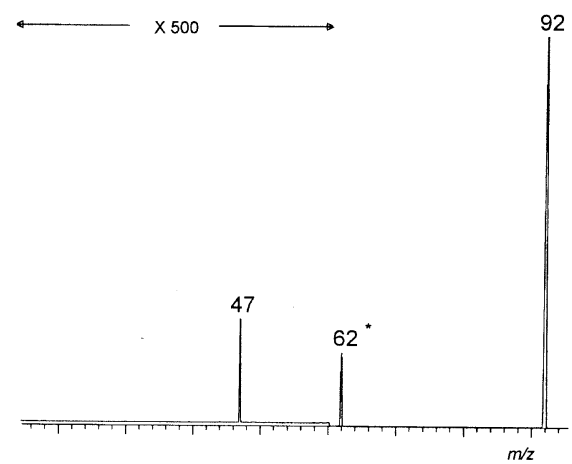

(b)

Figure 6. Ion-molecule reactions between (a) mass-selected $\left[\mathrm{CH}_{3} \mathrm{SH}, \mathrm{NO}\right]^{+}(\mathrm{m} / z \mathrm{z})$ and (b) mass-selected $\left[\mathrm{CH}_{3} \mathrm{SCH}_{3}, \mathrm{NO}\right]^{+}$ $(\mathrm{m} / \mathrm{z}$ 92) and ammonia in the quadrupole cell. The signals marked by an asterisk correspond to the decomposition product of the mass-selected ions.

ammonia and methanol in the rf-only quadrupole cell installed in our 6-sector instrument.

First, the $\mathrm{NO}^{+}$transfer from $\left[\mathrm{R}_{1} \mathrm{SR}_{2}, \mathrm{NO}\right]^{+}$complexes to methanol is never observed whatever the starting thio compound is. This is of course in close agreement with the computed data presented in Tables 3 and 4, as the NOA is always greater for an $S$-base when compared to an O-base.

On the other hand, the reaction between $\left[\mathrm{R}_{1} \mathrm{SH}, \mathrm{NO}\right]^{+}$ adduct ions and ammonia always leads to the transfer of the nitrosonium cation to the neutral substrate.

The protonation of ammonia is also observed in each case, see Figure 6a in the case of methanethiol. Following our G2(MP2) calculations, it is possible to calculate the heats of both the observed reactions, see Scheme 3 .

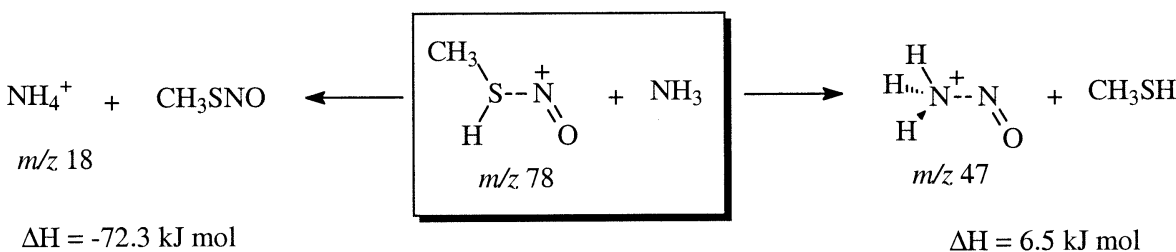

Scheme 3 
<smiles>CCCC[C@@H](C)CC</smiles>

$\Delta \mathrm{H}=43.7 \mathrm{~kJ} \mathrm{~mol}$

Scheme 4

At this level of theory, the $\mathrm{NO}^{+}$and $\mathrm{H}^{+}$transfer reactions to ammonia are calculated to be endothermic by $6.5 \mathrm{~kJ} \mathrm{~mol}^{-1}$ and exothermic by $72.3 \mathrm{~kJ} \mathrm{~mol}^{-1}$, respectively.

As far as the $\mathrm{NO}^{+}$transfer process is concerned, the occurrence of slightly endothermic processes in our experimental setting is not unexpected since no thermalization step precedes the ion-molecule reaction processes and therefore hot ions can not be expelled from the ion beam [8].

However, as exemplified in the case of the dimethylsulfide nitrosonium complex, the endothermicity of the $\mathrm{NO}^{+}$transfer reaction, amounting to 43.7 at the B3LYP/6-31 + G(d,p) level of theory, is too endothermic to allow this process to occur, see Scheme 4 , and accordingly virtually no $\mathrm{NO}^{+}$cation transfer is observed during the interaction in the quadrupole cell between $[\mathrm{MeSMe}, \mathrm{NO}]^{+}$cations and ammonia, see Figure $6 \mathrm{~b}$.

\section{Conclusions}

The interaction between the nitrosonium cation, $\mathrm{NO}^{+}$, and some selected compounds such as ammonia and methylamine, water and methanol, hydrogen sulfide and methanethiol, and dimethyl sulfide was considered theoretically by means of the G2(MP2) theory and DFT calculations and experimentally by the use of tandem mass spectrometry techniques. At the G2(MP2) level of theory, the nitrosonium cation affinities of $\mathrm{H}_{3} \mathrm{~N}, \mathrm{H}_{2} \mathrm{O}$, $\mathrm{H}_{2} \mathrm{~S}, \mathrm{MeNH}_{2}, \mathrm{MeOH}$ and MeSH are calculated, respectively, as follow: $125.7,77.9,80.6,178.8,102.1$, and 132.2 $\mathrm{kJ} \mathrm{mol}^{-1}$. These values allow us to conclude that the NOA's increase when going from an O-base to an $\mathrm{N}$-base via an $\mathrm{S}$-base and also increase upon replacement of an hydrogen atom by a methyl group.

The nitrosation of thiol and thioether compounds in the gas phase starting with an alkyl nitrite was also explored and it was demonstrated that (1) a proton is required in the nitrosation of thiol by alkyl nitrite, (2) that in the gas phase this proton could be initially borne either by the thiol compound or the nitrite, and (3) since proton transfer type reactions are observed, that a protonated dimer can be proposed as the intermediate species.

\section{Acknowledgments}

The authors thank the Fonds National pour la Recherche Scientifique for its contribution to the acquisition of our large scale tandem mass spectrometer, Micromass AutoSpec 6F. PG also thanks the FNRS for continuing support.

\section{References}

1. Butler, A. R.; Flitney, F. W.; Williams, D. L. H. NO, Nitrosonium Ions, Nitroxide Ions, Nitrosothiols, and Iron-Nitrosyls in Biology: A Chemist's Perspective. TiPS 1995, 16, 18-22.

2. Delamere, C.; Lewars, E.; Rafferty, S. The Bonding of Nitrosonium Ion to Sulfur in Models of Cytochrome c-type Biomolecules: An ab Initio Computational Study. J. Mol. Struct. (Theochem.) 2002, 582, 27-38.

3. Hughes, M. N. Relationships Between Nitric Oxide, Nitroxyl Ion, Nitrosonium Cation, and Peroxynitrite. Biochim. Biophys. Acta 1999, 1411, 163-272.

4. Myers, P. R.; Mior, R. L.; Guerra, R. L.; Bates, J. N.; Harrison, G. Vasorelaxant Properties of the Endothelium-Derived Relaxing Factor More Closely Resemble S-Nitrosocysteine than Nitic Oxide. Nature 1990, 345, 161-163.

5. Stamler, J. S.; Jia, L.; Eu, J. P.; McMahon, T. J.; Demchenko, I. T.; Bonaventura, J.; Gernert, K.; Piantadosi, C. A. Blood Flow Regulation by S-Nitrosohemoglobin in the Physiological Oxygen Gradient. Science 1997, 276, 2034-3037.

6. Stamler, J. S. Redox Signaling-Nitrosylation and Related Target Interactions of Nitric Oxide. Cell 1994, 78, 931.

7. Bateman, R. H.; Brown, J.; Lefevere, M.; Flammang, R.; Van Haverbeke, Y. Applications in Gaseous Ion and Neutral Chemistry Using a 6-Sector Mass Spectrometer. Int. J. Mass. Spectrom. Ion Processes 1992, 115, 205-218.

8. Flammang, R.; Van Haverbeke, Y.; Braybrook, C.; Brown, J. A New Hybrid Mass Spectrometer for the Investigation of Ion-Molecule Reactions. Rapid Commun. Mass Spectrom. 1995, 9, 795-799.

9. Frisch, M. J.; Trucks, G. W.; Schlegel, H. B.; Scuserai, G. E.; Robb, M. A.; Cheeseman, J. R.; Zakrzewski, V. G.; Montgomery, J. A.; Stratmann, R. E.; Burant, J. C.; Dapprich, S.; Millam, J. M.; Daniels, A. D.; Kudin, K. N.; Strain, M. C.; Farkas, O.; Tomasi, J.; Barone, V.; Cossi, M.; Cammi, R.; Mennucci, B.; Pomelli, C.; Adamo, C.; Clifford, S.; Ochterski, J.; Petersson, G. A.; Ayala, P. Y.; Cui, Q.; Morokuma, K.; Malick, D. K.; Rabuck, A. D.; Raghavachari, K.; Foresman, J. B.; Cioslowski, J.; Ortiz, J. V.; Stefanov, B. B.; Liu, B. B.; Liashenko, A.; Piskorz, P.; Komaromi, A.; Gomperts, R.; Martin, R. L.; Fox, D. J.; Keith, T.; Al-Laham, M. A.; Peng, C. Y.; Nanayakkara, M. W.; Gonzalez, C.; Challacombe, M.; Gill, P. M. W.; Johnson, B. G.; Chen, W.; Wong, M. W.; Andres, J. L.; Head-Gordon, M.; Reploge, E. S.; Pople, J. A. Gaussian 98; Gaussian, Inc: Pittsburg, PA, 1998.

10. (a) Curtiss, L. A.; Raghavachari, K.; Trucks, G. W.; Pople, J. A. Gaussian-2 Theory for Molecular Energies of 1st-Row and 2nd-Row Compounds. J. Chem. Phys. 1991, 94, 7221. (b) Curtiss, L. A.; Raghavachari, K.; Pople, J. A. Gaussian-2 Theory Using Reduced Møller-Plesset Orders. J. Chem. Phys. 1993, 98, 1293-1298. (c) Smith, B. J.; Radom, L. Calculations of Proton Affinities Using the G2(MP2,SVP) Procedure. J. Phys. Chem. 1995, 99, 6468-6471.

11. Borodkin, G. I.; Shubin, V. G. Nitrosonium Complexes of Organic Compounds. Structure and Reactivity. Russ. Chem. Rev. 2001, 70, 211-230.

12. Francisco, J. S. Protonated Nitrous Acid $\left(\mathrm{H}_{2} \mathrm{ONO}^{+}\right)$: Molecular Structure, Vibrational Frequencies, and Proton Affinity. J. Chem. Phys. 2001, 115, 2117-2122.

13. Kulkarni, S. A.; Pundlik, S. S. Ab Initio Study of Protonated Nitrosamide: A Possible Intermediate in the deNOx Process. Chem. Phys. Lett. 1995, 245, 143-149.

14. Aschi, M.; Grandinetti, F. Protonated Methyl Nitrite. A Theoretical Investigation on the Structure and Stability of $(\mathrm{MeO}-$ 
$\mathrm{NO}) \mathrm{H}^{+}$and the Proton Affinity of RO-NO $(\mathrm{R}=\mathrm{H}, \mathrm{Me})$. Chem. Phys. Lett. 1996, 258, 123-128.

15. French, M. A.; Hills, L. P.; Kebarle, P. Kinetics and Temperature Dependence of the Hydration of $\mathrm{NO}^{+}$in the Gas Phase. Can. J. Chem. 1973, 51, 456-461.

16. Reents, W. D.; Freiser, B. S. Gas-Phase Binding Energies and Spectroscopic Properties of $\mathrm{NO}^{+}$Charge-Transfer Complexes. J. Am. Chem. Soc. 1981, 103, 2791-2797.

17. Cacace, F.; De Petris, G.; Pepi, F. Gas-Phase $\mathrm{NO}^{+}$Affinities. Proc. Natl. Acad. Sci. U.S.A. 1997, 94, 3507-3512.

18. Aschi, M.; Grandinetti, F. Gaseous Protonated Nitrosamide. A G2 Theoretical Study on the Structure, Stability, and Interconversion of the $\left(\mathrm{H}_{2} \mathrm{~N}-\mathrm{NO}\right) \mathrm{H}^{+}$Isomers. Chem. Phys. Lett. 1997, 267, 98-104.

19. Nguyen, M. T.; Lahem, D.; Flammang, R. The Gas-Phase $\mathrm{R}_{\mathrm{n}} \mathrm{X}-\mathrm{NO}^{+}(\mathrm{X}=\mathrm{O}, \mathrm{N}, \mathrm{S})$ Cations: Nitroso Onium Cations versus Ion-Molecule Complexes. Chem. Phys. Lett. 1998, 283, 357-362.

20. (a) Torday, L. L.; Santillan, M. B.; Ciuffo, G. M.; Jauregui, E. A.; Pataricza, J.; Gy-Papp, J.; Csizmadia, I. M. Lewis Acidity of $\mathrm{NO}^{+}$and $\mathrm{NO}_{2}^{+}$as Measured by Their Affinity to Selected Bases. An ab Initio Background Study of Biological NO Release. J. Mol. Struct. Theochem. 1999, 465, 69-78. (b) Cacace, F.; Ciuffo, G. M.; de Petris, G. Concerning the Lewis Acidity of $\mathrm{NO}^{+}$and $\mathrm{NO}_{2}^{+}$as Measured by Their Affinity to Selected Bases. J. Mol. Struct. Theochem. 2000, 507, 277-279.

21. De Petris, G. Di; Marzio, A.; Grandinetti, F. $\mathrm{H}_{2} \mathrm{NO}_{2}^{+}$Ions in the Gas Phase. A Mass Spectrometric and Post-SCF Ab Initio Study. J. Phys. Chem. 1991, 95, 9782-9787.

22. Nguyen, M. T.; Hegarty, A. F. An ab Initio Calculation of the Acid-Catalysed Hydrolysis of N-Nitrosamines. A Hypothesis on the Rate-Determining Step. J. Chem. Soc. Perkin Trans. 2 1987, 345-349.
23. Nguyen, M. T.; Hegarty, A. F. Protonation of Nitrous Acid and Formation of the Nitrosating Agent $\mathrm{NO}^{+}$: An Ab Initio Study. J. Chem. Soc. Perkin Trans. 2 1984, 2037-2041.

24. Egsgaard, H.; Carlsen, L.; Madsen, J. O. Protonated Nitrosamide. An Intermediate in a Possible deNOx Process. Chem. Phys. Lett. 1994, 227, 33-38.

25. Lias, S. G.; Bartmess, J. E.; Liebman, J. F.; Holmes, J. L.; Levin, R. D.; Mallard, W. G. Gas-Phase Ion and Neutral Thermochemistry. J. Phys. Chem. Reference Data 1988, 17, Suppl 1.

26. Farid, R.; McMahon, T. B. Gas-Phase Ion-Molecule Reactions of Alkyl Nitrites by Ion Cyclotron Resonance Spectroscopy. Int. J. Mass Spectrom. Ion Phys. 1978, 27, 163-183.

27. Jorgensen, K. A.; El-Wassimy, M. T. M.; Lawesson, S.-O. On the Formation of Nitrosation Reagents. Acta Chem. Scand. Ser. B 1983, 37, 785-790.

28. Pearson, R. G. Symmetry Rules for Chemical Reactions. Orbital Topology and Elementary Processes; Wiley: New York, NY, 1976.

29. Borodkin, G. I.; Podryvanov, V. A.; Shakirov, M. M.; Shubin, V. G. Interaction of Anisole and Thioanisole with the Nitrosonium Cation: $\pi$-versus n-Complex Formation. J. Chem. Soc. Perkin Trans. 2 1995, 1029.

30. (a) Raghavachari, K.; Reents, W. D. ; Haddon, R. C. . Gas-Phase Nitrosation of Benzene: Theoretical Investigations . J. Comput. Chem. 1986, 7, 265-273. (b) Dechamps, N., Gerbaux, P., Flammang, R., Bouchoux, G., Nguyen, M.-T. Gas-Phase Nitrosation of Substituted Benzenes. Int. J. Mass Spectrom., in press.

31. Spanel, P.; Smith, D. Selected Ion Flow Tube Studies of the Reactions of $\mathrm{H}_{3} \mathrm{O}^{+}, \mathrm{NO}^{+}$, and $\mathrm{O}_{2}^{+}$with Some Organosulphur Molecules. Int. J. Mass Spectrom. 1998, 176, 167-176.

32. Tsikas, D.; Raida, M.; Sandmann, J.; Rossa, S.; Forssmann, W.-G.; Frölich, J. C. Electrospray Ionization Mass Spectrometry of Low-Molecular-Mass S-Nitroso Compounds and Their Thiols. J. Chromatogr. B 2000, 742, 99-108. 